\title{
Developmental and Reproductive Effects of SE5-OH: An Equol-Rich Soy-Based Ingredient
}

\author{
Ray A. Matulka, ${ }^{1}$ Ikuo Matsuura, ${ }^{2}$ Tohru Uesugi, ${ }^{3}$ Tomomi Ueno, ${ }^{4}$ and George Burdock ${ }^{1}$ \\ ${ }^{1}$ Burdock Group, Orlando, FL 32801, USA \\ ${ }^{2}$ The Safety Assessment Division II, Mitsubishi Chemical Safety Institute Ltd., Tokyo 105-0014, Japan \\ ${ }^{3}$ The Department of Toxicology, Otsuka Pharmaceutical Co. Ltd., Tokushima 771-0192, Japan \\ ${ }^{4}$ The Saga Nutraceuticals Research Institute, Otsuka Pharmaceutical Co. Ltd., Tokushima 771-0192, Japan \\ Correspondence should be addressed to Ray A. Matulka, rmatulka@burdockgroup.com
}

Received 29 May 2008; Revised 7 August 2008; Accepted 7 October 2008

Recommended by Robert Tanguay

Consumption of the isoflavones daidzein, genistein, glycitein, and their structural analogues is generally considered beneficial to human health. Equol is not found in soy, but is converted from daidzein by human gut bacterial flora. Research indicates that between $30-50 \%$ of the population is capable of converting daidzein to equol; therefore, there has been recent development of a new equol-rich functional food that relies on bacterial conversion of daidzein to equol under strictly controlled conditions. Therefore, a new equol-rich soy product (SE5-OH) has been developed, based on the bacterial conversion of daidzein; and its reproductive and developmental toxicity has been evaluated in a two-generation study and a developmental toxicity study with Sprague-Dawley rats at dose levels of 200,1000 , and $2000 \mathrm{mg} / \mathrm{kg} /$ day by gavage. SE5-OH contains approximately $0.65 \%$ equol, $0.024 \%$ daidzein, $0.022 \%$ genistein, and $0.30 \%$ glycitein. From the reproductive study, the no-observed-adverse-effect-level (NOAEL) for SE5-OH determined for both male and female rats is $1000 \mathrm{mg} / \mathrm{kg} /$ day $(6.5 \mathrm{mg}$ equol $/ \mathrm{kg} / \mathrm{day})$. In the developmental toxicity phase of the study, no effects by SE5-OH were found in the embryo-fetus at any of the doses tested. The NOAEL for developmental effects of SE5-OH is $2000 \mathrm{mg} / \mathrm{kg} /$ day $(13 \mathrm{mg}$ equol $/ \mathrm{kg} /$ day).

Copyright ( $) 2009$ Ray A. Matulka et al. This is an open access article distributed under the Creative Commons Attribution License, which permits unrestricted use, distribution, and reproduction in any medium, provided the original work is properly cited.

\section{Introduction}

Over the past two decades, scientific literature has indicated that consumption of soy products and, in particular, their isoflavone components have been associated with the reduction of the risk of cancer, coronary vascular disease, osteoporosis, and other pathologies that are associated with menopause and ageing in both sexes [1-3]. One such isoflavone is equol: a microbial metabolite of daidzein, which is structurally related to $17 \beta$-estradiol [4]. Consumption of daidzein in subjects that were found to be able to metabolize daidzein to equol has been linked with delay in the onset of menopause and menopausal-associated symptoms, markers of cardiovascular disease, and prostate cancer $[5,6]$; however, there is conflicting evidence concerning the ability to produce equol and subsequent health benefits $[6,7]$. Although there are known dietary sources of equol, the levels of equol in these milk samples are relatively low (in the range of
$60-450 \mathrm{ng}$ equol/mL) $[8,9]$. Therefore, the consumption of equol-enriched soy-based products may be of health benefit to individuals who do not convert daidzein to equol.

In nature, equol is formed exclusively by the intestinal microbiota although chemical synthesis pathways have also been described $[10,11]$. The enzymatic process of producing equol from daidzein resides with the gut microbial flora [12, 13], similar to the pathway presented in Figure 1. Although it has been estimated that there are more than 400 species of bacteria in the human gut that may influence the normal structure and function of the intestinal system $[14,15]$, research indicates that, depending upon the population studied, between $30-50 \%$ of the population is host to bacteria which metabolize daidzein into equol $[6,16,17]$. Recent research has indicated that humans that host bacteria, able to metabolize daidzein to equol, convert approximately $30-40 \%$ of daidzein into equol, and the types of food consumed may be one of several factors that affect the ability 
TABLE 1: Isoflavone constituents of SE5-OH.

\begin{tabular}{lcc}
\hline Isoflavone ingredient & Reproductive toxicity study (Lot 060106P) $)^{* *}(\mathrm{mg} / \mathrm{g})$ & $\begin{array}{c}\text { Reproductive toxicity study and developmental } \\
\text { toxicity study }(\text { Lot } 051206 \mathrm{P})^{* *}(\mathrm{mg} / \mathrm{g})^{*}\end{array}$ \\
\hline Daidzein & $0.323 \pm 0.0015$ & $0.275 \pm 0.0025$ \\
Genistein & $0.293 \pm 0.0017$ & $0.287 \pm 0.0032$ \\
Glycitein & $1.65 \pm 0.015$ & $2.04 \pm 0.010$ \\
Dihydrodaidzein & $0.362 \pm 0.0021$ & $0.337 \pm 0.0036$ \\
Equol & $5.16 \pm 0.070$ & $5.24 \pm 0.025$ \\
\hline
\end{tabular}

*The amount of each isoflavone ingredient is the average of three separate measurements, mean \pm standard deviation.

** Both lots were used in the reproductive study, while only Lot $051206 \mathrm{P}$ was used in the developmental study.<smiles>CCOC(=O)c1coc2cc(O)ccc2c1=O</smiles>

FIgURE 1: Daidzein metabolism to equol.

to produce equol [18-20]. Serum levels of equol in equol producers that consume daidzein have been noted at up to $76 \pm 137 \mathrm{nmol} / \mathrm{L}$.

The content of equol in the soy-based product (SE5$\mathrm{OH}$ ) has been enriched as a result of fermentation of soy germ with the bacterium L. garvieae (Otsuka Pharmaceutical Co., Ltd., Chiyoda-ku, Tokyo, Japan). L. garvieae is not a normal member of the human gut flora, but is typically found in fish, and within fish aquacultures, and is associated with decreased growth rates, an unmarketable appearance, and mortality, but is not known to produce toxins [21]. L. garvieae is a rare pathogen with a low virulence in humans with gastrointestinal disorders that consumed raw fish, also has been found in several different cheeses, and may be an important fermentation microbe in the production of several cheeses, including artisanal Italian and traditional Egyptian Domiati cheeses [22-25]. The controlled process of soy fermentation with L. garvieae is capable of converting approximately $50 \%$ of the daidzein contained within the soy to equol. SE5-OH is autoclaved to kill the bacteria, and subsequently analyzed to ensure that SE5-OH does not contain any living L. garvieae; therefore, the live organism will not be ingested by the consumer.

Previously, we have reported acute and subchronic toxicity studies of SE5-OH in the adult rat model, and determined the NOAEL to be $2000 \mathrm{mg} / \mathrm{kg} /$ day following administration for 90 days [26]. The objective of the studies described herein was to investigate the effect of the specific equolenriched soy-based SE5-OH product on rat development and reproduction over two generations.

\section{Methods and Materials}

2.1. Test Articles. The test article, referred to as SE5-OH, was prepared by a controlled fermentation of a daidzeinrich soy germ containing isoflavones with L. garvieae (Otsuka
Pharmaceutical Co., Ltd., Chiyoda-ku, Tokyo, Japan). SE5$\mathrm{OH}$ contains approximately $0.65 \%$ equol, $0.024 \%$ daidzein, $0.022 \%$ genistein, and $0.30 \%$ glycitein. The test article is a light brown powder that includes five specific isoflavones; the amounts in the two lots of test article used in these studies are presented in Table 1. The test article control was hydroxypropylmethylcellulose (HPMC), supplied by ShinEtsu Chemical Co., Ltd (Chiyoda-ku, Tokyo, Japan).

2.2. Animals. Male and/or female Crl:CD(SD) rats, supplied by the Atsugi Breeding Center of Charles River Laboratories (CRL) Japan, Inc., (Kohoku-ku, Yokohama, Japan) were used for both the developmental and reproductive toxicity studies. All animals were clinically monitored at the time of delivery to the testing facility and during the acclimation period. Housing consisted of stainless steel or polycarbonate cages, with a twelve-hour light period (7:00 AM to 7:00 PM). Temperature was maintained at $20.1-23.4^{\circ} \mathrm{C}$ with a relative humidity of $49.6-69.2 \%$ and $6-20$ air changes/h. The bedding, which was used only in the reproductive toxicity study, was of the Beta-Chip brand supplied by Charles River Laboratories Japan, Inc. The rats were six weeks of age at the start of dosing in the reproductive toxicity study and twelve weeks of age at mating in the developmental toxicity study. Rats were acclimatized for five or six days before use.

2.3. Guidelines. The developmental toxicity and reproductive toxicity studies were carried out under the guidelines of Redbook 2000 and FDA's Toxicological Principles for the Safety Assessment of Food Ingredients [27, 28]. Both studies were conducted within the Good Laboratory Practice (GLP) standards for the conduction of nonclinical studies on the safety of drugs (Ministry of Health and Welfare (MHW), Japan, Ordinance Number 21, 26 March 1997, [http://pdg-a258.koyosha.co.jp/jsqa2/en/glp/glp424e.html]). This study was approved by the Committee of Kashima 
Laboratory for Ethics in Animal Studies in compliance with "Guidelines for Animals Studies (Kashima Laboratory, Mitsubishi Chemical Safety Institute Ltd., Kamisu-shi, Ibaraki, Japan)."

\subsection{Experimental Design}

\subsubsection{Developmental Toxicity Study}

(1) Exposure and Observations. On gestational days (GDs) 6-19, three groups of 22 pregnant females were administered doses of SE5-OH in $1 \%$ aqueous HPMC by gavage at levels of 200,1000 , and $2000 \mathrm{mg} / \mathrm{kg} /$ day, respectively; the control group (22 pregnant females) was administered 1\% HPMC vehicle only. Animals were observed twice daily for clinical signs during the dosing period, and once daily following the dosing regimen. Body weights and gross weights of the diets were measured on GD 0,6, 8, 10, 12, 14, 16, 18, and 20 . Body weight gain was calculated on the basis of body weights measured on GD 6.

(2) Necropsy. On GD 20, dams were euthanized, the gravid uterus was collected from each dam and weighed to allow for calculation of corrected body weight and corrected body weight gain. Corrected body weight was determined by subtracting the gravid uterine weight from the body weight on GD 20, while the corrected body weight gain was calculated by subtracting the body weight on GD 6 from the corrected body weight. At necropsy of the dams, thoracic and abdominal organs and tissues were examined macroscopically. Any organs or tissues showing abnormalities were collected and preserved. If such collections were conducted, the same tissues were collected from three control dams and also preserved. Ovaries and uterus were removed and examined for the number of corpora lutea, implantations, live fetuses, and dead embryos. Early embryonic deaths were considered to be represented by the number of implantation sites plus placental remnants; late embryonic deaths were represented by macerated embryos plus dead fetuses.

Live fetuses were weighed, euthanized, sexed, and examined (external and oral cavity examinations). Approximately half of the live fetuses in each litter from the control and the $2000 \mathrm{mg} / \mathrm{kg}$ dose dams were subjected to visceral examination, which included the head, neck, thorax, and abdomen. The remaining fetuses were examined for skeletal anomalies and degrees of ossification in cervical vertebral bodies, sternebrae, metacarpi, metatarsi, and sacral/caudal vertebral bodies.

2.4.2. Reproductive Toxicity Study. Groups of 52 rats (26/sex/ group) served as the $\mathrm{F}_{0}$ generation and were administered the same SE5-OH test article at the same doses via gavage as in the developmental toxicity study (i.e., 0, 200, 1000, and $2000 \mathrm{mg} / \mathrm{kg} /$ day). Dosing commenced at six weeks of age and lasted for ten weeks before mating and then throughout the mating period. The mating procedure involved the placement of one male and one female in the same cage for a maximum of two weeks, with reproductive capacity judged by copulation index, fertility index, precoital period, gestation period, and gestation index. $\mathrm{F}_{0}$ females that became pregnant continued on this exposure regimen through gestation and lactation until weaning of the $\mathrm{F}_{1}$ animals. The $\mathrm{F}_{1}$ generation males and females were also administered the same dosing regimen of SE5-OH, beginning on postnatal day (PND) 21, for ten to eleven weeks before mating and throughout the mating period, with pregnant females continuing on the dosing schedules through gestation and lactation until weaning of the $\mathrm{F}_{2}$ generation. Throughout this entire process, animals were observed twice daily for clinical signs; body weights and food consumption were measured weekly until the start of gestation in both $\mathrm{F}_{0}$ and $F_{1}$ generations. Estrous cycle was examined for three weeks before the start of mating in both $\mathrm{F}_{0}$ and $\mathrm{F}_{1}$ females. During gestation, females in both generations were weighed on GD $0,3,7,10,14,17$, and 20 and then on lactation day (LD) 0 , $4,7,10,14,17$, and 21 during lactation. Food consumption was also measured during GD $0,7,14$, and 20 and on LD 0 , $4,7,14$, and 21 . On the day after the animals reached the end of their respective exposure periods, they were euthanized for gross necropsy. The following tissues were weighed and preserved: adrenals, brain, kidney, liver, female reproductive tissues (uterus, ovaries), male reproductive tissues (testes, epididymis, prostate, and seminal vesicles including coagulating glands), pituitary, spleen, thymus (neonatal only), and thyroid gland. Histological examinations were conducted on tissues from control and high- $(2000 \mathrm{mg} / \mathrm{kg})$ dose groups only and included adrenals $\left(\mathrm{F}_{0}\right.$ females were examined in all dose groups), male and female reproductive organs, pituitary, and liver tissues from $\mathrm{F}_{0}$ females. Sperm was also collected from the cauda epididymis of all $\mathrm{F}_{0}$ and $F_{1}$ males and evaluated for motility, and the sperm from the control and $2000 \mathrm{mg} / \mathrm{kg}$ dose group were also evaluated for spermatid cells (testis), sperm number, and morphology.

Clinical parameters for offspring included examination for external anomalies, sex ratios, live birth index (i.e., number of live pups/number of total pups born), as well as viability index on PND 4 and weaning index on PND 21; pup weights were measured at birth as well as PND 4, 7, 14, and 21. On PND 4, litter sizes were adjusted randomly to eight pups per dam. Pups were also examined for physical and functional developmental parameters, which included incisor eruption, eye opening, reflexes for righting, auditory startle, pain, corneal, and pupillary reactions. Sexual maturation was determined in $\mathrm{F}_{1}$ rats by recording the age and weight on the day of vaginal opening after PND 27 was reached or when balanopreputial separation from PND 35 was recorded. At gross necropsy of $F_{1}$ and $\mathrm{F}_{2}$ weanlings, brain, spleen, and thymus were collected from selected animals for preservation (one male and one female selected from each litter in numerical order of the offspring number in each litter, which was randomly assigned). Ovaries, vagina, and uterus were collected from females, while testes, epididymis, seminal vesicles, and prostate were collected from males. Organ weights were determined from one animal of each sex per litter for brain, thymus, spleen, and uterus. 
2.5. Statistical Analyses. Statistical analysis for the reproductive and developmental toxicity study was conducted using several different tests, using the toxicological data processing system (MiTOX, Mitsui Zosen Systems Research, Inc., Japan). The data of offspring obtained before weaning were analyzed on the basis of litter mean values except for the sex ratio. The normality of the data was assumed, unless otherwise indicated. Homogeneity of variance was tested by Bartlett's test; when the data were homogeneous, a one-way analysis of variance (ANOVA) was performed for statistical comparison. Heterogeneous data were tested by the KruskalWallis test. When a significant intergroup difference was found, Dunnett's or the Dunnett-type multiple comparison test was used. For some of the data (e.g., days until copulation, number of estrus stages without copulation, gestation length, sperm motility, birth index, viability index on PND 0,4 , and 21 , incidence of offspring with external anomalies, postnatal physical development, reflex and sensory function, as well as sexual maturation (vaginal opening and cleavage of balanopreputial gland)), the Kruskal-Wallis test was applied first, and when a significant intergroup difference was found, the Dunnett-type multiple comparison test was used. The multiple comparison test was utilized to evaluate statistical significance of changes in body weight, body weight gain, food consumption, organ weights, number of implantations, number of offspring, number of live offspring, and estrous cycle lengths. However, for the spermatid count and sperm count, the homogeneity of variance was tested by the $\mathrm{F}$ test, and when the variance was homogeneous, Student's $t$-test was performed for the statistical comparison. When heterogeneous, the Aspin-Welch $t$-test was used. Moreover, Wilcoxon's rank sum test was used for comparison of the incidence of abnormal sperm (morphologically abnormal sperm and tailless sperm), visceral examination, and skeletal examinations. The categorical data (e.g., copulation index, fertility index, gestation index, sex ratio (male/female), incidence of females with irregular estrous cycles, and dams with external abnormal offspring) were analyzed by Fisher's exact probability test. All statistical tests used two-tailed significance level of $5 \%$.

\section{Results}

\subsection{Developmental Toxicity Study}

3.1.1. Effects on Dams. With the exception of a transient lack of weight gain (see Figure 2), no abnormal clinical signs were observed in any of the dams. This included observations for death, moribundity, abortion, or premature delivery (data not shown). In dams exposed to $2000 \mathrm{mg} / \mathrm{kg}$, significant decreases in body weight gain were noted on GD 8-16 but these values had returned to control levels by GD 20 . The same transient lack of weight gain was noted for dams in the $1000 \mathrm{mg} / \mathrm{kg}$ exposure group, but only on GD 8. No treatment-related effects were seen for food consumption, gravid uterine weights, corrected body weight, and corrected body weight gain; and there were no abnormalities seen at necropsy (data not shown).

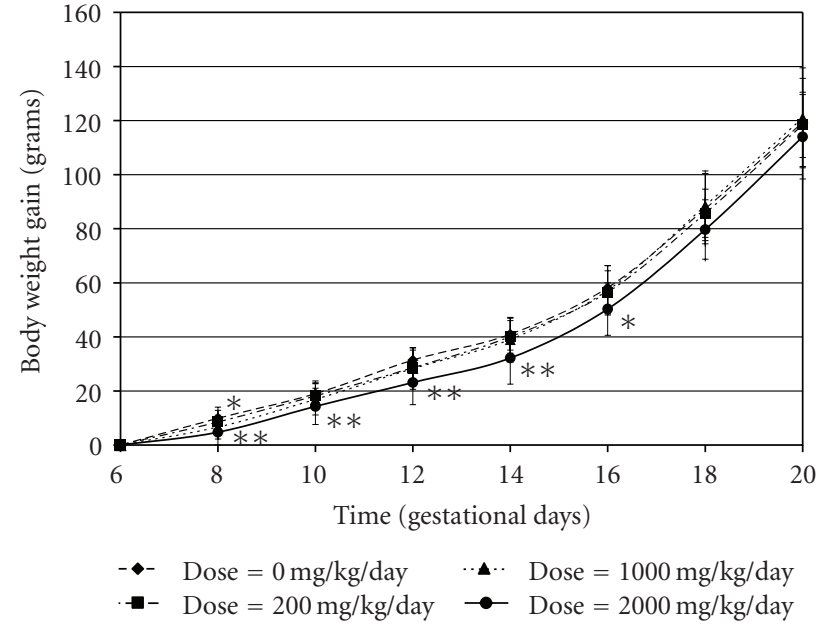

FIGURe 2: Changes in body weight gain (grams) observed in dams exposed to SE5-OH during gestational days 0-20 during the developmental toxicity study in rats; significant when compared to control: ${ }^{*} P<.05 ;{ }^{* *} P<.01$

3.1.2. Effects on Embryo-Fetal Development. In all treated groups, there were no significant differences in number of corpora lutea, implantations, dead embryos, postimplantation losses, live fetuses, fetal deaths, fetal weight, or sex ratio. Several isolated embryo-fetal effects were noted during the placental observations, and external, visceral, and skeletal examinations. These changes are summarized in Table 2.

\subsection{Reproductive Toxicity Study}

3.2.1. Parental Animals. Transient decrease of weight gain and reduced food intake in the $F_{0}$ and $F_{1}$ females of $2000 \mathrm{mg} / \mathrm{kg} / \mathrm{day}$, and histological change of adrenal cortex (a diffuse increase in lipid droplets in the zona glomerulosa) in the $\mathrm{F}_{0}$ females of $2000 \mathrm{mg} / \mathrm{kg} /$ day were noted (see Table 3). Food intake was reduced in the $\mathrm{F}_{0}$ females in the $1000 \mathrm{mg} / \mathrm{kg} /$ day group. In addition, increased liver weight in the $\mathrm{F}_{0}$ female of 1000 and $2000 \mathrm{mg} / \mathrm{kg} /$ day dose groups, increased adrenal weight in the $\mathrm{F}_{0}$ males at the $2000 \mathrm{mg} / \mathrm{kg} /$ day dose group, as well as increased thyroid weight in the $F_{1}$ males (see Table 4) was noted. No adverse clinical signs (including death, moribundity, abortion, or premature delivery), necropsy findings, or organ weights were observed in any of the $\mathrm{F}_{0}$ and $\mathrm{F}_{1}$ parental animals.

There were no adverse reproductive effects observed in any treatment group of $\mathrm{F}_{0}$ and $\mathrm{F}_{1}$ animals in terms of estrous cycle, copulation index, fertility index, or precoital period (see Tables 5 and 6). No adverse effects were seen in gestation period, gestation index, or parturition. No effect on implantation number was found in the $\mathrm{F}_{0}$ generation although the number of implantations was slightly, but significantly, reduced in the $F_{1}$ dams at $2000 \mathrm{mg} / \mathrm{kg} /$ day, there were no effects on implantation in the 200 and $1000 \mathrm{mg} / \mathrm{kg} / \mathrm{da} \mathrm{F}_{1}$ generation (see Tables 7 and 8). The decrease in implantation number in the high dose did not significantly affect the birth index or the number of 
TABLE 2: Isolated embryo-fetal effects noted during necropsy observations/examinations in the developmental toxicity study in rats.

Effect

Fusion of placentae

Rudimentary tail

Visceral anomaly: ventricular septal defect

Visceral variants: thymic neck remnant, supernumerary coronary ostium, left umbilical artery, and renal pelvis dilation

Skeletal anomalies/malformations: wavy and nodulated ribs

Skeletal variants: foramen hypoglossi double, closure of transverse foramen of one or more cervical vertebral arches, transverse foramen opening in 7th cervical arch, splitting of ossification centers in thoracic vertebral bodies, hemicentric thoracic centrum, dumbbell ossification of thoracic centrum, lumbarization, cervical ribs, short supernumerary 14 th rib, reduced 13 th ribs, splitting of sternebrae
Occurrence

Occurred in one dam in the $200 \mathrm{mg} / \mathrm{kg}$ dose group. No other placental abnormalities identified in any group.

Occurred in one fetus of the $1000 \mathrm{mg} / \mathrm{kg}$ dose group. No other external fetal abnormalities identified in any group.

Occurred in one control group fetus and one $2000 \mathrm{mg} / \mathrm{kg}$ group fetus. No other anomalies identified in any group.

Occurred with equal incidence in the control and $2000 \mathrm{mg} / \mathrm{kg}$ groups.

Occurred in one $2000 \mathrm{mg} / \mathrm{kg}$ group fetus. No other anomalies identified in any group.

Incidence of dumbbell ossification of thoracic centrum was significantly low in the $2000 \mathrm{mg} / \mathrm{kg}$ dosing group but was judged incidental with no toxicological significance. offspring born alive. SE5-OH administration to male rats did not affect any of the sperm parameters evaluated, which included sperm motility, percentage and type of abnormal sperm, tailless sperm, sperm count, or the number of homogenization-resistant sperm (see Table 9).

3.2.2. Offspring Development. Reproductive performance for the $\mathrm{F}_{0}$ generation was initiated with 26 mating pairs. While not statistically significant, 2, 2, and 1 pairs in the 200, 1000 , and $2000 \mathrm{mg} / \mathrm{kg} /$ day dose groups, respectively, did not copulate. In the copulating pairs, nonpregnant females were observed in 1, 2, and 3 cases of the control, 1000, and $2000 \mathrm{mg} / \mathrm{kg} /$ day groups, respectively; again, this did not result in a significant difference in the fertility index. The $\mathrm{F}_{0}$ breeding resulted in $25,24,22$, and 22 dams in the control, 200, 1000 , and $2000 \mathrm{mg} / \mathrm{kg} /$ day dose groups, respectively. The number of litters delivered resulted in 24, 23, 22, and 22 litters/dose in the control, 200, 1000, and $2000 \mathrm{mg} / \mathrm{kg} /$ day dose groups, respectively (see Table 10). One complete litter in the $1000 \mathrm{mg} / \mathrm{kg} /$ day dose group was lost on PND 2.

For $\mathrm{F}_{1}$ rat pups, one male and one female were randomly selected from each litter on PND 21 and were used as breeding animals in the $\mathrm{F}_{1}$ generation (siblings not paired). One male pup in the control group died on PND 21, and one female $1000 \mathrm{mg} / \mathrm{kg} /$ day pup died on PND 22. In addition, two $F_{1}$ females in the control group and one $F_{1}$ male in the $1000 \mathrm{mg} / \mathrm{kg}$ group that had no mating partner were not subjected to mating. This resulted in $22,23,20$, and 22 breeding $F_{1}$ pairs in the control, 200, 1000, and $2000 \mathrm{mg} / \mathrm{kg} /$ day dose groups, respectively. All mating pairs copulated except for one pair in each of the control and $200 \mathrm{mg} / \mathrm{kg} /$ day groups. Three, 3, 1, and 1, nonpregnant females occurred in control, 200, 1000, and $2000 \mathrm{mg} / \mathrm{kg} /$ day dose groups, respectively. One female died with vaginal hemorrhage on GD 23 in the $200 \mathrm{mg} / \mathrm{kg} /$ day dose group, which was not considered to be test article-related. One male of the control group could not fertilize the mating female, and one male of the $2000 \mathrm{mg} / \mathrm{kg} /$ day dose group exhibited unilateral small and soft testis and small epididymis, and the mated female of this male had only one implantation with no delivery. These effects were not significant and not considered to be related to test article administration, as they were not dose-related responses. Of the dose groups, $18,18,19$, and $21 \mathrm{~F}_{1}$ dams gave birth to live $\mathrm{F}_{2}$ offspring (see Table 11). There were no changes attributable to the test article in parturition or nursing. Total litter loss was observed for one dam each in the 200 and $2000 \mathrm{mg} / \mathrm{kg}$ /day dose groups on PND 4 and PND 1, respectively; however, this was judged to be incidental as this was not a dose-dependent effect.

In the $\mathrm{F}_{2}$ generation, the number of female offspring was reduced at the $2000 \mathrm{mg} / \mathrm{kg} /$ day dose on PND $4(P<$ $.05)$, but neither the number of live offspring on PND 21 nor the viability index was affected. This reduction was not caused by prenatal death or a difference in the birth index, but was only a reflection of a nonsignificant reduction in the number of implantations. The total litter loss on PND 1 was judged to be incidental, as there was no dose dependency in the incidence and no abnormalities in the maternal behavior in the dams. There were no adverse effects observed in any treatment group of $F_{1}$ and $F_{2}$ offspring: clinical signs, body weight, external anomalies, sex ratios, viability index, physical development, reflex function, organ weight, necropsy findings, and sexual maturation (data not shown), or viability index (see Table 11).

\section{Discussion}

Soy is the most widely used food plant in the world and has been cultivated for over 4500 years, resulting in human soy isoflavone consumption for several millennia [29]. Recently 
TABLE 3: Body weight and food consumption in male and female Sprague-Dawley rats during the two-generation reproductive toxicity study.

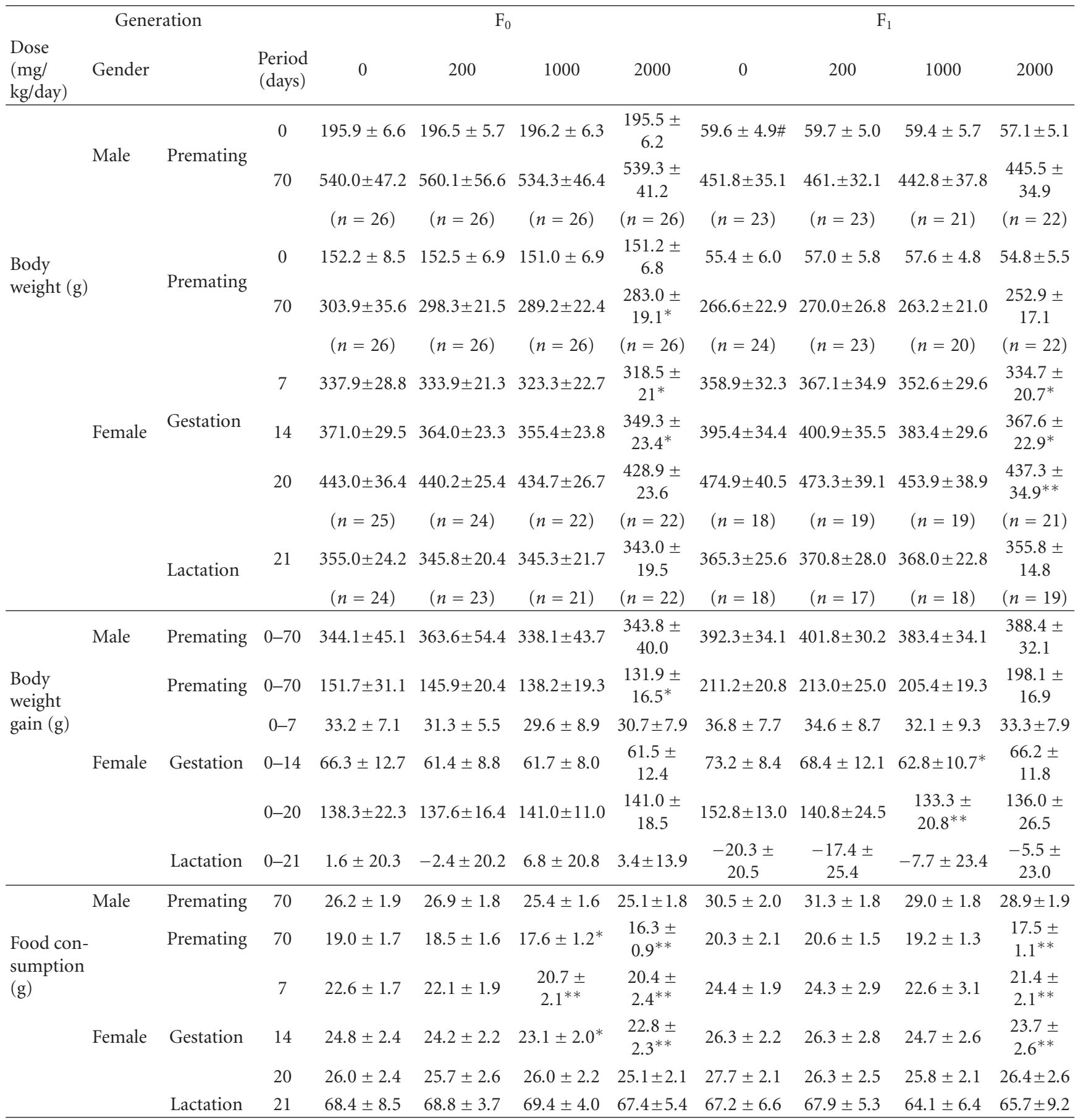

Mean \pm standard deviation; significantly different from control: ${ }^{*} P<.05, * * P<.01$; \# the start of dosing for the $\mathrm{F}_{0}$ groups was at six weeks of age. The start of dosing for the $\mathrm{F}_{1}$ group was on day 21 postparturition, to maintain SE5-OH ingestion via lactation; $n$ : number of male and female rats per dose group.

published data by the USDA [30] indicate that daidzein, genistein, and glycitein are constituents in a wide variety of legumes, prepared foods, spices, teas, and of course, soybased foods, including infant formula, tofu, tempeh, cheese, beverages, noodles, sauces, chips, and meat substitutes. In unfermented food products, the glycosylated forms (i.e., daidzin, genistin, glycitin, and their derivatives) are more abundant than the aglycone forms. The widespread historical exposure to soy isoflavones in the diet, without adverse human health effects, and the overall body of available scientific evidence, is a compelling evidence of their safety. While average Japanese isoflavone intake has been estimated at $50 \mathrm{mg} /$ day, western consumption is approximated at $5 \mathrm{mg} /$ day $[31,32]$. 
TABLE 4: Organ weight changes in male and female breeding Sprague-Dawley rats in the $\mathrm{F}_{0}$ and $\mathrm{F}_{1}$ generations of the two-generation rat study.

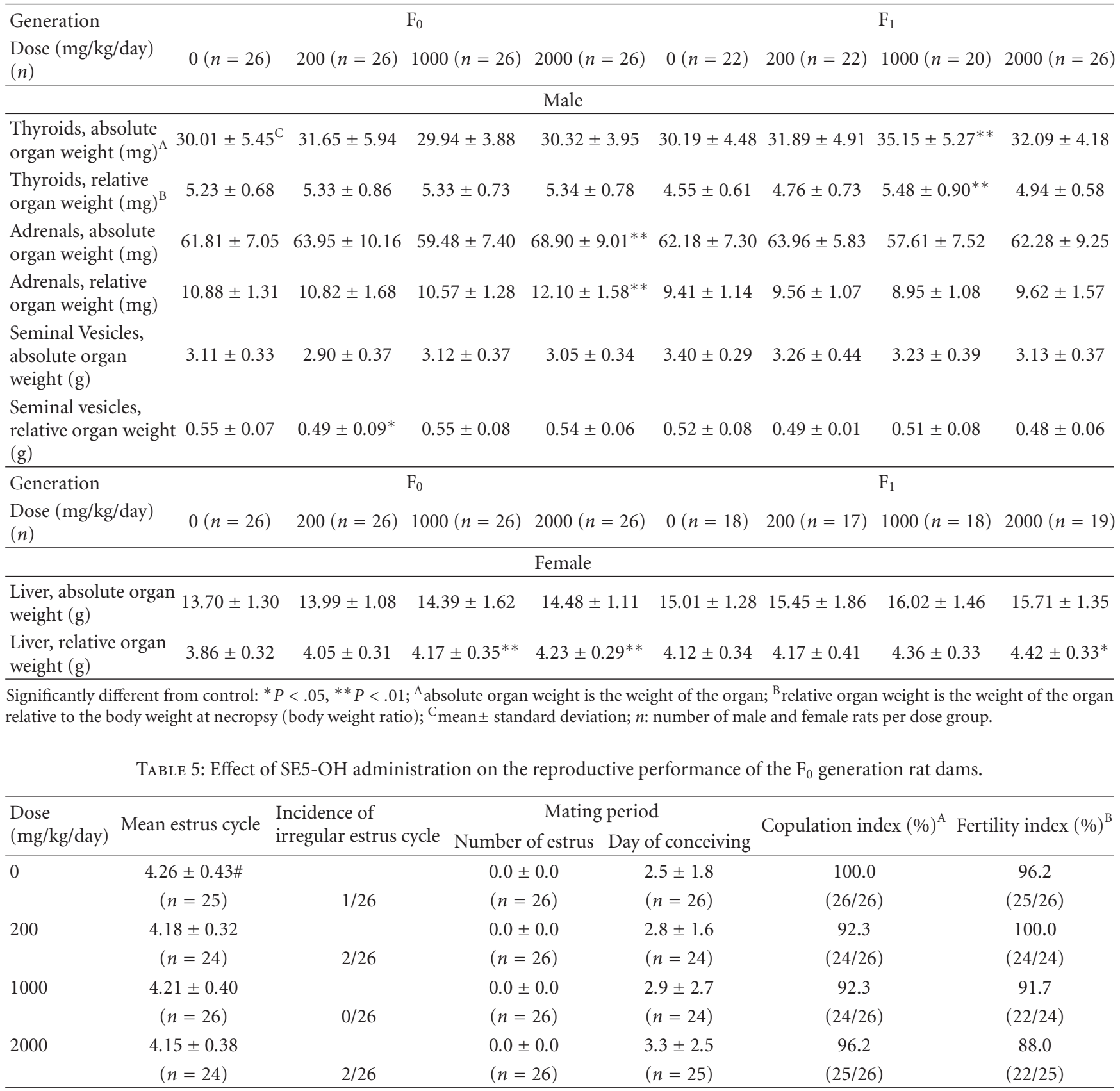

\#Mean \pm standard deviation; ${ }^{\mathrm{A}}$ number of copulated females/number of pairs; ${ }^{\mathrm{B}}$ number of pregnant females/number of copulated females; $n$ : number of mating pairs.

There has been a concern that ingestion of soy isoflavones may lead to adverse effects on testes and ovaries [33-36]. Unlike diethylstilbestrol (DES), equol at $1000 \mu \mathrm{g} /$ animal/day injected subcutaneously for five days failed to demonstrate estrogenic, or antiestrogenic activity in the uterine wall of neonatal Sprague-Dawley (SD) rats [37]. Other research found that equol administration directly to the uterine horn in ovariectomized rats did not increase uterine weight, and although equol did weakly bind to the estrogen receptor with a high dissociation rate, it did not demonstrate antiestrogenic activity [38]. In concert with findings reported by Thompson et al. [38], Wood et al. [39] found that high doses of genistein and daidzein or equol had minimal uterotrophic or mammotrophic effects in an ovariectomized monkey (Macaca fascicularis) model. In the normal postmenopausal mammary gland of cynomolgus macaques, equol at an equivalent human dose of $105 \mathrm{mg} /$ day for greater than six months lacked estrogenic effects, and did not promote lesions in the mammary tissue [40]. Rachon et al. [4143] found that equol in the diet at $400 \mathrm{mg}$ per $\mathrm{kg}$ of food 
TABLE 6: Effect of SE5-OH administration on the $\mathrm{F}_{1}$ generation rat dam reproductive performance.

\begin{tabular}{|c|c|c|c|c|c|c|}
\hline \multirow{2}{*}{$\begin{array}{l}\text { Dose } \\
\text { (mg/kg/day) }\end{array}$} & \multirow{2}{*}{ Mean estrus cycle } & \multirow{2}{*}{$\begin{array}{l}\text { Incidence of } \\
\text { irregular estrus cycle }\end{array}$} & \multicolumn{2}{|c|}{ Mating period } & \multirow{2}{*}{ Copulation index $(\%)^{\mathrm{A}}$} & \multirow{2}{*}{ Fertility index $(\%)^{\mathrm{B}}$} \\
\hline & & & Number of estrus & Day of conceiving & & \\
\hline \multirow[t]{2}{*}{0} & $4.36 \pm 0.46 \#$ & & $0.1 \pm 0.6$ & $3.1 \pm 2.8$ & 95.5 & 85.7 \\
\hline & $(n=24)$ & $0 / 24$ & $(n=22)$ & $(n=21)$ & $(21 / 22)$ & $(18 / 21)$ \\
\hline \multirow[t]{2}{*}{200} & $4.31 \pm 0.45$ & & $0.2 \pm 0.7$ & $2.8 \pm 1.8$ & 95.7 & 86.4 \\
\hline & $(n=21)$ & $2 / 23$ & $(n=23)$ & $(n=22)$ & $(22 / 23)$ & $(19 / 22)$ \\
\hline \multirow[t]{2}{*}{1000} & $4.39 \pm 0.41$ & & $0.1 \pm 0.2$ & $2.3 \pm 1.3$ & 100.0 & 95.0 \\
\hline & $(n=20)$ & $0 / 20$ & $(n=20)$ & $(n=20)$ & $(20 / 20)$ & $(19 / 20)$ \\
\hline \multirow[t]{2}{*}{2000} & $4.30 \pm 0.43$ & & $0.0 \pm 0.0$ & $2.5 \pm 1.5$ & 100.0 & 95.5 \\
\hline & $(n=21)$ & $1 / 22$ & $(n=22)$ & $(n=22)$ & $(22 / 22)$ & $(21 / 22)$ \\
\hline
\end{tabular}

\#Mean \pm standard deviation; ${ }^{\mathrm{A}}$ number of copulated females/number of pairs; ${ }^{\mathrm{B}}$ number of pregnant females/number of copulated females; $n$ : number of mating pairs.

TABLE 7: Effects of SE5-OH administration on $\mathrm{F}_{0}$ generation rat dam gestation and delivery parameters.

\begin{tabular}{|c|c|c|c|c|c|c|}
\hline $\begin{array}{l}\text { Dose } \\
(\mathrm{mg} / \mathrm{kg} / \text { day })\end{array}$ & & $\begin{array}{c}\text { Gestation length } \\
\text { (days) }\end{array}$ & $\begin{array}{c}\text { Number of } \\
\text { implantation sites }\end{array}$ & $\begin{array}{c}\text { Number of offspring } \\
\text { born alive }\end{array}$ & Birth index ${ }^{A}(\%)$ & Gestation index ${ }^{\mathrm{B}}(\%)$ \\
\hline \multirow[t]{2}{*}{0} & & $22.3 \pm 0.5$ & $15.0 \pm 3.9$ & $13.8 \pm 4.1$ & $87.12 \pm 21.64$ & 96 \\
\hline & $n$ & 24 & 25 & 25 & 25 & \\
\hline \multirow[t]{2}{*}{200} & & $22.2 \pm 0.4$ & $15.1 \pm 3.6$ & $13.8 \pm 3.4$ & $89.03 \pm 20.48$ & 95.8 \\
\hline & $n$ & 23 & 24 & 24 & 24 & \\
\hline \multirow[t]{2}{*}{1000} & & $22.3 \pm 0.6$ & $15.3 \pm 1.7$ & $13.6 \pm 3.3$ & $89.27 \pm 19.68$ & 100.0 \\
\hline & $n$ & 22 & 22 & 22 & 22 & \\
\hline \multirow[t]{2}{*}{2000} & & $22.0 \pm 0.3$ & $14.7 \pm 2.1$ & $13.8 \pm 2.3$ & $93.63 \pm 9.28$ & 100.0 \\
\hline & $n$ & 22 & 22 & 22 & 22 & \\
\hline
\end{tabular}

Significantly different from control: ${ }^{*} P<.05,{ }^{* *} P<.01$; ${ }^{\mathrm{A}}$ birth index $=$ (number of offspring born alive divided by the number of implantations); ${ }^{\mathrm{B}}$ gestation index $=$ (number of females with live offspring divided by the number of pregnant females); $n$ : number of dams per group.

(delivering approx. $26.16 \mathrm{mg}$ equol $/ \mathrm{kg}$ body weight/day to the rat) for three months to ovariectomized rats significantly increased serum prolactin and lutenizing hormone levels $(P<.05)$, but had no effect on pituitary estrogen receptor (ER) $-\alpha$ or $-\beta$ gene expression. However, equol administration did increase an isoform of the estrogen receptor (Terp-1) in the pituitary of these ovariectomized rats, and increased the number of terminal ducts and type II lobules, compared to control rats. Equol dosed at $3.68 \mathrm{mg} / \mathrm{kg} / \mathrm{day}$ in this same study had no effect on rat mammary tissue. In this same rat model, equol ( $26.16 \mathrm{mg} / \mathrm{kg}$ body weight/day) significantly increased uterine weights and increased the epithelial height and thickness of the uterine stroma and myometrium, and significantly increased levels of uterine insulin-like growth factor 1 , progesterone receptor, and complement protein $3 \mathrm{mRNA}$, while $3.68 \mathrm{mg}$ equol $/ \mathrm{kg}$ bodyweight/day had no effect [44]. Subcutaneous administration of up to $1000 \mu \mathrm{g}$ equol in rat pups during PND 1-5 or PND 10-14 lowered uterine weight at later ages, but did not affect ER levels [45]. Equol administration (approx. $27.48 \mathrm{mg} / \mathrm{kg}$ body weight/day) in ovariectomized rats for six weeks increased uterine weight, decreased weight gain, and attenuated trabecular bone loss (but not proximal tibia bone loss), while increasing its density, indicating mild bone sparing effects [46]. These studies indicate that there is an uncertain degree of difference in species- and organ-specific sensitivity to equol administration.

SE5-OH is a unique fermented soy germ food product that is intended to deliver equol to individuals who cannot produce it endogenously. The studies currently described were conducted to determine any potential developmental and reproductive effects of SE5-OH. In the developmental study, isolated embryo-fetal effects were noted during necropsy, which included the fusion of placentae in one dam in the $200 \mathrm{mg} / \mathrm{kg} / \mathrm{day}$ dose group. As no other placental abnormalities were identified in this study, this effect was determined not to be test article-related. One control group fetus and one high-dose fetus were found to have a ventricular septal defect, and visceral variants that included a thymic neck remnant, supernumerary coronary ostium, left umbilical artery, and renal pelvis dilations which occurred with equal incidence in these dose groups and were determined not to be test article-related. Dumbell ossification of the thoracic centrum was significantly lower in the high-dose group, but the overall incidence of the observed skeletal variants (as indicated in Table 4) was determined not to be test article-related because they are similarly seen in untreated $\mathrm{Crl}: \mathrm{CD}(\mathrm{SD})$ rats.

An increase in relative (but not absolute) liver weight was noted in the $\mathrm{F}_{0} 1000$ and $2000 \mathrm{mg} / \mathrm{kg} / \mathrm{day}$ dams, and 
TABLE 8: Effects of SE5-OH administration on $\mathrm{F}_{1}$ generation rat dam gestation and delivery parameters.

\begin{tabular}{|c|c|c|c|c|c|}
\hline $\begin{array}{l}\text { Dose } \\
(\mathrm{mg} / \mathrm{kg} / \text { day })\end{array}$ & $\begin{array}{c}\text { Gestation length } \\
\text { (days) }\end{array}$ & $\begin{array}{c}\text { Number of } \\
\text { implantation sites }\end{array}$ & $\begin{array}{l}\text { Number of offspring } \\
\text { born alive }\end{array}$ & Birth index ${ }^{\mathrm{A}}(\%)$ & Gestation index $^{\mathrm{B}}(\%)$ \\
\hline \multirow[t]{2}{*}{0} & $22.2 \pm 0.4$ & $15.8 \pm 1.2$ & $14.9 \pm 1.9$ & $93.8 \pm 7.4$ & 100 \\
\hline & $n=18$ & $n=18$ & $n=18$ & $n=18$ & \\
\hline \multirow[t]{2}{*}{200} & $22.2 \pm 0.4$ & $15.8 \pm 2.5$ & $14.0 \pm 2.3$ & $88.9 \pm 9.2$ & 100 \\
\hline & $n=18$ & $n=18$ & $n=18$ & $n=18$ & \\
\hline \multirow[t]{2}{*}{1000} & $22.2 \pm 0.4$ & $13.8 \pm 4.1$ & $12.7 \pm 3.9$ & $88.1 \pm 22.8$ & 94.7 \\
\hline & $n=18$ & $n=19$ & $n=19$ & $n=19$ & \\
\hline \multirow[t]{2}{*}{2000} & $22.3 \pm 0.6$ & $12.6 \pm 4.7^{*}$ & $11.3 \pm 5.1$ & $84.5 \pm 24.8$ & 95.2 \\
\hline & $n=20$ & $n=21$ & $n=21$ & $n=21$ & \\
\hline
\end{tabular}

${ }^{\mathrm{A}}$ Birth index $=$ (number of offspring born alive divided by the number of implantations); ${ }^{\mathrm{B}}$ gestation index $=$ (number of females with live offspring divided by the number of pregnant females); $n$ : number of dams per group.

TABLE 9: Sperm parameters in control and high-dose male rats used as breeding males in the $\mathrm{F}_{0}$ and $\mathrm{F}_{1}$ two-generation reproduction study.

\begin{tabular}{|c|c|c|c|c|c|c|c|c|c|c|}
\hline \multirow{2}{*}{$\begin{array}{l}\text { Dose } \\
(\mathrm{mg} / \mathrm{kg} / \text { day })\end{array}$} & \multirow{2}{*}{$\begin{array}{l}\text { Sperm } \\
\text { motility (\%) }\end{array}$} & \multirow{2}{*}{$\begin{array}{l}\text { HRS } \\
\left(\times 10^{6} / \mathrm{g}\right)\end{array}$} & \multirow{2}{*}{$\begin{array}{l}\text { Sperm count (cauda } \\
\text { epididymal })\left(\times 10^{6} / \mathrm{g}\right)\end{array}$} & \multirow{2}{*}{$\begin{array}{l}\text { Abnormal } \\
\text { sperm }(\%)\end{array}$} & \multicolumn{5}{|c|}{ Types of abnormal sperm (\%) no. } & \multirow{2}{*}{$\begin{array}{l}\text { Tailless } \\
\text { sperm }(\%)\end{array}$} \\
\hline & & & & & A & B & C & $\mathrm{D}$ & E & \\
\hline \multicolumn{11}{|c|}{$\mathrm{F}_{0}$ generation } \\
\hline 0 & $91.0 \pm 4.5$ & $83.73 \pm 12.52$ & $534.73 \pm 72.79$ & $0.81 \pm 1.26$ & $\begin{array}{c}0.25 \pm \\
0.62\end{array}$ & $\begin{array}{c}0.04 \pm \\
0.14\end{array}$ & $\begin{array}{c}0.00 \pm \\
0.00\end{array}$ & $\begin{array}{c}0.42 \pm \\
0.76\end{array}$ & $\begin{array}{c}0.10 \pm \\
0.40\end{array}$ & $1.96 \pm 2.03$ \\
\hline$n$ & 26 & 26 & 26 & 26 & 26 & 26 & 26 & 26 & 26 & 26 \\
\hline 2000 & $91.3 \pm 3.2$ & $83.64 \pm 10.21$ & $537.29 \pm 66.92$ & $0.33 \pm 0.37$ & $\begin{array}{c}0.04 \pm \\
0.14\end{array}$ & $\begin{array}{c}0.00 \pm \\
0.00\end{array}$ & $\begin{array}{c}0.00 \pm \\
0.00\end{array}$ & $\begin{array}{c}0.29 \pm \\
0.35\end{array}$ & $\begin{array}{c}0.00 \pm \\
0.00\end{array}$ & $1.81 \pm 2.83$ \\
\hline$n$ & 26 & 26 & 26 & 26 & 26 & 26 & 26 & 26 & 26 & 26 \\
\hline \multicolumn{11}{|c|}{$\mathrm{F}_{1}$ generation } \\
\hline 0 & $86.0 \pm 20.1$ & $75.98 \pm 17.86$ & $551.21 \pm 151.94$ & $0.52 \pm 0.83$ & $\begin{array}{c}0.31 \pm \\
0.43\end{array}$ & $\begin{array}{c}0.00 \pm \\
0.00\end{array}$ & $\begin{array}{c}0.00 \pm \\
0.00\end{array}$ & $\begin{array}{c}0.21 \pm \\
0.62\end{array}$ & $\begin{array}{c}0.00 \pm \\
0.00\end{array}$ & $1.95 \pm 1.77$ \\
\hline$n$ & 22 & 22 & 22 & 21 & 21 & 21 & 21 & 21 & 21 & 21 \\
\hline 2000 & $86.7 \pm 19.7$ & $81.57 \pm 14.31$ & $557.51 \pm 142.72$ & $0.40 \pm 0.71$ & $\begin{array}{c}0.19 \pm \\
0.51\end{array}$ & $\begin{array}{c}0.00 \pm \\
0.00\end{array}$ & $\begin{array}{c}0.00 \pm \\
0.00\end{array}$ & $\begin{array}{c}0.21 \pm \\
0.34\end{array}$ & $\begin{array}{c}0.00 \pm \\
0.00\end{array}$ & $5.18 \pm 15.30$ \\
\hline$n$ & 22 & 22 & 22 & 22 & 22 & 22 & 22 & 22 & 22 & 22 \\
\hline
\end{tabular}

A: without hook, B: banana-like head, C: amorphous, D: folded in midpiece, E: others; HRS: homogenization-resistant spermatids; $n$ : number of males per group.

in the $2000 \mathrm{mg} / \mathrm{kg} /$ day $F_{1}$ dams, but was not seen in the male rats. The increase at the $1000 \mathrm{mg} / \mathrm{kg} /$ day dose did not exceed the limits of $5 \%$ variability, which is generally considered within the accepted level of variability to the control rats. The relative liver weight at the $2000 \mathrm{mg} / \mathrm{kg} / \mathrm{day}$ dose had greater than $5 \%$ variability from controls. There was a significant increase in the absolute and relative thyroid weight in the $1000 \mathrm{mg} / \mathrm{kg} / \mathrm{day}$ dose group, but this was not considered related to SE5-OH treatment, as this effect was not noted in any other dose levels. The highest dose of SE5$\mathrm{OH}(2000 \mathrm{mg} / \mathrm{kg} /$ day $)$ had some indications of toxicity at the gestational and conception stages in the rat model.

The adrenal cortex of $F_{0}$ females at the $2000 \mathrm{mg} / \mathrm{kg} / \mathrm{day}$ SE5-OH dose had an increased number of diffuse lipid droplets (4/10 in the high-dose group versus $0 / 10$ in the controls) noted in the glomerular zone of the adrenal glands. Lipid droplets are the intracellular stores of cholesterol esters, precursors of hormones formed in the rat adrenal glands [47]. It has been documented that cell enlargement and widening of the zona glomerulosa of the adrenal cortex (associated with an increase in lipid droplet volume) may be induced via androgen receptor binding, and that isoflavones (including equol as an antiandrogen [48]) have been reported to alter androgen receptor expression and adrenocortical function $[49,50]$. However, the exact mechanism is not known, as isoflavones have been shown to increase or decrease androgen production, depending on the model used [51-54]. Wood et al. [53] noted that consumption of a soy protein providing $129 \mathrm{mg} /$ day isoflavones (which provided approx. $31 \mathrm{mg}$ daidzein per day) by female cynomolgus monkeys for 36 months did not alter serum androgen levels, but decreased adrenal weight $(P<.0006)$. However, previous postmenopausal oral contraceptive administration abolished this effect $(P<.01)$. Diffuse lipid droplets in the adrenal cortex have been noted in the rat model as a consequence of advancing age [47], and coupled with pregnancy, they may have been a factor in the results of this study. The maximal plasma concentration was $390 \pm$ 90 and $414 \pm 32 \mathrm{ng} / \mathrm{mL}$, respectively, for the S- and Renantiomers. 
TABLE 10: Litter size and viability index of the $\mathrm{F}_{1}$ generation rat pups exposed to SE5-OH during gestation and through lactation of the $\mathrm{F}_{0}$ dams.

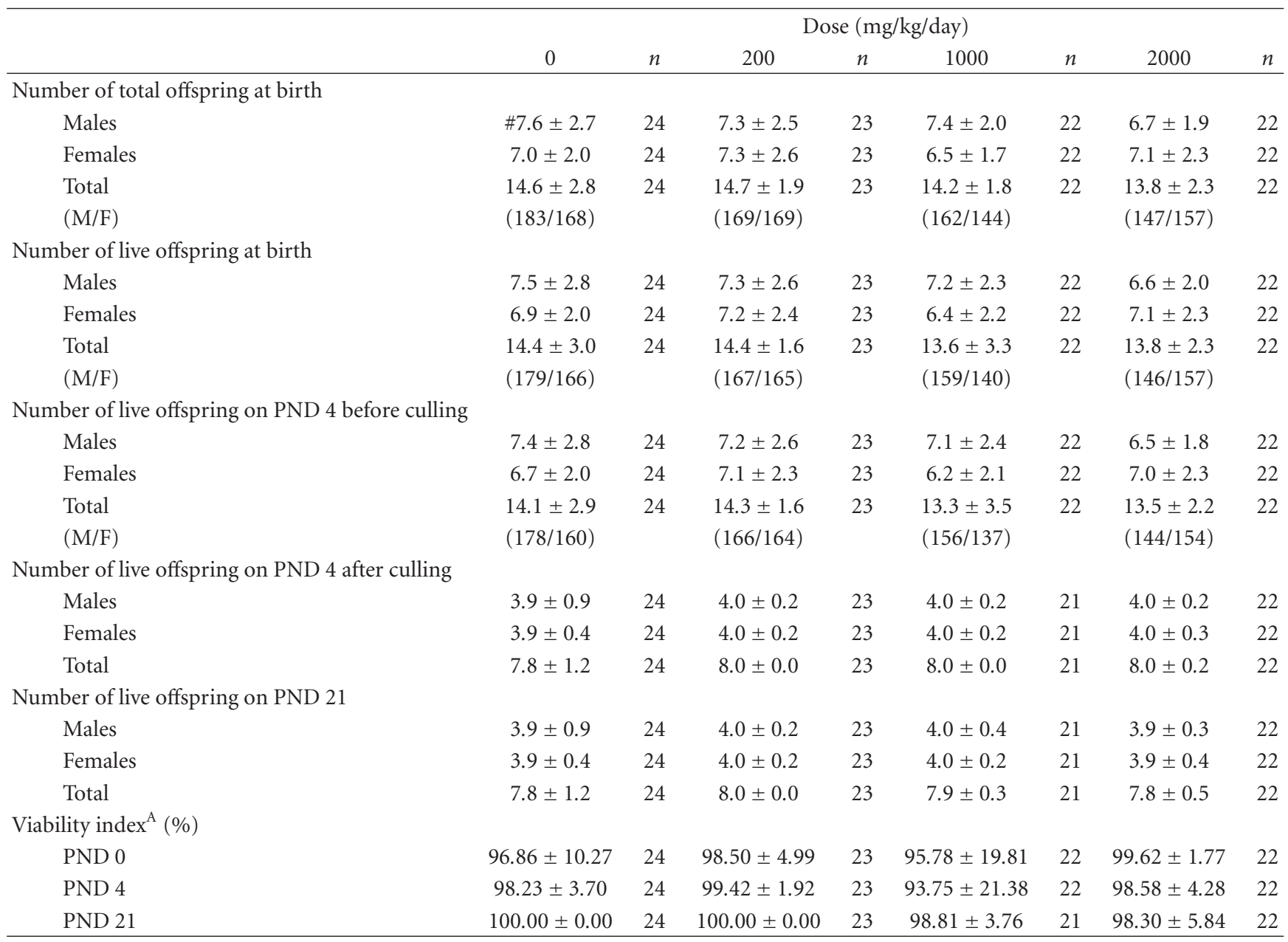

\#Mean \pm standard deviation; $n$ : number of litters; PND: postnatal day; ${ }^{A}$ viability index: PND 0: (number of live offspring born alive/number of offspring born), PND 4: (number of offspring alive on PND 4/number of offspring born alive), PND 21: (number of live weanlings/number of live offspring after culling).

Although a significant reduction in the number of implantations in this study is thought to have occurred due to lowered caloric intake in the high-dose pregnant dams, it still remains that there was an overall adverse effect, albeit an indirect one (i.e., an effect of reduced caloric intake on decreased body weights) and not a product of the intrinsic toxicity of SE5-OH on the reproductive ability of the rats in this study. Even though a transient decrease in body weight gain was noted in $\mathrm{F}_{0}$ and $\mathrm{F}_{1}$ dams of the $2000 \mathrm{mg} / \mathrm{kg} /$ day dose group, no changes were observed in fetal viability, intrauterine growth, and fetal morphology (external, skeletal, and visceral) that were attributed to SE5-OH treatment. Isolated embryo-fetal alterations were noted, but were not consistent with SE5-OH treatment or significantly different from controls. It is known that food restriction affects the adult female rat reproductive capacity and may decrease the number of corpus luteum graviditatis $[55,56]$. Equol administration to ovariectomized rats at approximately $27.48 \mathrm{mg} / \mathrm{kg} /$ day for six weeks [44] resulted in decreased weight gain, intra-abdominal fat, plasma leptin, and total cholesterol levels. Soy isoflavone administration to male, female, and ovariectomized rats reduced food intake and weekly body weight gain, while increasing serum isoflavones, including equol [57]. A decrease in implantations was noted at the $2000 \mathrm{mg} / \mathrm{kg}$ /day dose group; however, since no adverse effects were noted on organ weights or histopathological examination of the reproductive organs, mating ability, fertility, pregnancy, parturition, or nursing behavior in $\mathrm{F}_{0}$ or $\mathrm{F}_{1}$ animals, this slight decrease in implantation number was not a substantive or meaningful effect. Further, the absence of an effect on the fecundity of the high-dose animals in the reproduction study indicates this decrease in implantation was an anomalous finding, and is supported by the lack of reproductive toxicity by daidzein in rats reported by Lamartiniere et al. [34]. In a previous work [26], no adverse observations were found in adult rats at up to $2000 \mathrm{mg} / \mathrm{kg} / \mathrm{day}$ SE5$\mathrm{OH}$ in a subchronic 90-day study. In the present study, no adverse toxicological observations were made at either the reproductive or developmental stages in the either sex 
TABLE 11: Litter size and viability index of the $\mathrm{F}_{2}$ generation rat pups exposed to SE5-OH during gestation through lactation.

\begin{tabular}{|c|c|c|c|c|c|c|c|c|}
\hline & \multicolumn{8}{|c|}{ Dose (mg/kg/day) } \\
\hline & 0 & $n$ & 200 & $n$ & 1000 & $n$ & 2000 & $n$ \\
\hline \multicolumn{9}{|c|}{ Number of total offspring at birth } \\
\hline Males & $\# 8.0 \pm 2.8$ & 18 & $7.9 \pm 2.5$ & 18 & $6.9 \pm 1.8$ & 18 & $6.9 \pm 2.9$ & 20 \\
\hline Females & $7.0 \pm 2.4$ & 18 & $6.6 \pm 2.7$ & 18 & $6.6 \pm 2.2$ & 18 & $5.5 \pm 2.7$ & 20 \\
\hline Total & $15.0 \pm 1.9$ & 18 & $14.4 \pm 2.2$ & 18 & $13.5 \pm 2.5$ & 18 & $12.4 \pm 4.2$ & 20 \\
\hline$(\mathrm{M} / \mathrm{F})$ & $(144 / 126)$ & & $(142 / 118)$ & & $(124 / 119)$ & & $(137 / 109)$ & \\
\hline \multicolumn{9}{|c|}{ Number of live offspring at birth } \\
\hline Males & $8.0 \pm 2.8$ & 18 & $7.6 \pm 2.6$ & 18 & $6.9 \pm 1.8$ & 18 & $6.6 \pm 3.0$ & 20 \\
\hline Females & $6.9 \pm 2.3$ & 18 & $6.4 \pm 2.5$ & 18 & $6.6 \pm 2.3$ & 18 & $5.4 \pm 2.8$ & 20 \\
\hline Total & $14.9 \pm 1.9$ & 18 & $14.0 \pm 2.3$ & 18 & $13.4 \pm 2.5$ & 18 & $11.9 \pm 4.5$ & 20 \\
\hline$(\mathrm{M} / \mathrm{F})$ & $(144 / 124)$ & & $(137 / 115)$ & & $(124 / 118)$ & & $(131 / 107)$ & \\
\hline \multicolumn{9}{|c|}{ Number of live offspring on PND 4 before culling } \\
\hline Males & $7.8 \pm 2.7$ & 18 & $7.2 \pm 3.1$ & 18 & $6.4 \pm 2.1$ & 18 & $6.4 \pm 3.2$ & 19 \\
\hline Females & $6.8 \pm 2.3$ & 18 & $6.9 \pm 3.0$ & 18 & $6.3 \pm 2.1$ & 18 & $5.2 \pm 3.0$ & 19 \\
\hline Total & $14.6 \pm 1.8$ & 18 & $13.2 \pm 4.0$ & 18 & $12.7 \pm 2.7$ & 18 & $11.5 \pm 5.0$ & 19 \\
\hline$(\mathrm{M} / \mathrm{F})$ & $(140 / 122)$ & & $(130 / 107)$ & & $(115 / 113)$ & & $(127 / 103)$ & \\
\hline \multicolumn{9}{|c|}{ Number of live offspring on PND 4 after culling } \\
\hline Males & $3.9 \pm 0.6$ & 18 & $4.2 \pm 0.7$ & 17 & $3.9 \pm 0.5$ & 18 & $3.9 \pm 1.0$ & 19 \\
\hline Females & $4.1 \pm 0.6$ & 18 & $3.8 \pm 0.7$ & 17 & $4.0 \pm 0.6$ & 18 & $3.4^{*} \pm 1.0$ & 19 \\
\hline Total & $8.0 \pm 0.0$ & 18 & $8.0 \pm 0.0$ & 17 & $7.9 \pm 0.2$ & 18 & $7.4^{*} \pm 1.3$ & 19 \\
\hline \multicolumn{9}{|c|}{ Number of live offspring on PND 21} \\
\hline Males & $3.8 \pm 0.6$ & 18 & $4.2 \pm 0.7$ & 17 & $3.8 \pm 0.6$ & 18 & $3.9 \pm 1.0$ & 19 \\
\hline Females & $4.1 \pm 0.5$ & 18 & $3.7 \pm 0.8$ & 17 & $4.0 \pm 0.6$ & 18 & $3.4 \pm 1.0$ & 19 \\
\hline Total & $7.9 \pm 0.3$ & 18 & $7.9 \pm 0.2$ & 17 & $7.8 \pm 0.5$ & 18 & $7.4 \pm 1.3$ & 19 \\
\hline \multicolumn{9}{|c|}{ Viability index ${ }^{\mathrm{A}}(\%)$} \\
\hline PND 0 & $99.23 \pm 2.23$ & 18 & $96.92 \pm 4.89$ & 18 & $99.54 \pm 1.96$ & 18 & $96.21 \pm 12.29$ & 20 \\
\hline PND 4 & $97.91 \pm 4.15$ & 18 & $93.61 \pm 23.49$ & 18 & $94.65 \pm 12.02$ & 18 & $94.43 \pm 22.30$ & 19 \\
\hline PND 21 & $98.61 \pm 4.04$ & 18 & $99.26 \pm 3.03$ & 17 & $98.51 \pm 4.34$ & 18 & $100.00 \pm 0.00$ & 19 \\
\hline
\end{tabular}

\#Mean \pm standard deviation; $n=$ number of litters; PND: postnatal day; ${ }^{A}$ viability index: PND 0: (number of live offspring born alive/number of offspring born), PND 4: (number of offspring alive on PND 4/number of offspring born alive), PND 21: (number of live weanlings/number of live offspring after culling).

of the rat model at the $1000 \mathrm{mg} / \mathrm{kg} /$ day dose. From the combined studies herein, we can conclude that in the developmental toxicity phase of the study, a no-observedadverse-effect-level (NOAEL) for developmental effects of SE5-OH is $2000 \mathrm{mg} / \mathrm{kg} /$ day, based on the lack of significant embryo-to-fetal stage effect. From the reproductive study, the NOAEL for SE5-OH determined for both male and female rats is $1000 \mathrm{mg} / \mathrm{kg} /$ day ( $6.5 \mathrm{mg}$ equol $/ \mathrm{kg} /$ day), based on the reduction of body weight, implantations, and live births in the $F_{1}$ and $F_{2}$ animals at the $2000 \mathrm{mg} / \mathrm{kg} /$ day dose level.

\section{Nomenclature}

ANOVA: Analysis of variance

DES: Diethylstilbestrol

ER: $\quad$ Estrogen receptor

GLP: $\quad$ Good laboratory practice

HPMC: Hydroxypropylmethylcellulose

MHW: $\quad$ Ministry of Health and Welfare (Japan)

NOAEL: No-observed-adverse-effect-level.

\section{Acknowledgments}

All studies described in this manuscript were conducted at Kashima laboratory of the Mitsubishi Chemical Safety Institute, Ltd. (Tokyo, Japan). All studies were sponsored by Tokushima Research Institute of Otsuka Pharmaceutical Co. Ltd. (Tokushima, Japan).

\section{References}

[1] L. Strauss, R. Santti, N. Saarinen, T. Streng, S. Joshi, and S. Mäkelä, "Dietary phytoestrogens and their role in hormonally dependent disease," Toxicology Letters, vol. 102-103, pp. 349354, 1998.

[2] J. W. Craig, "Health-promoting phytochemicals: beyond the traditional nutrients," in Vegetarian Nutrition, pp. 333-348, CRC Press, Boca Raton, Fla, USA, 2001.

[3] T. Usui, "Pharmaceutical prospects of phytoestrogens," Endocrine Journal, vol. 53, no. 1, pp. 7-20, 2006.

[4] S. J. Bhathena and M. T. Velasquez, "Beneficial role of dietary phytoestrogens in obesity and diabetes," The American Journal of Clinical Nutrition, vol. 76, no. 6, pp. 1191-1201, 2002. 
[5] C. Clerici, K. D. R. Setchell, P. M. Battezzati, et al., "Pasta naturally enriched with isoflavone aglycons from soy germ reduces serum lipids and improves markers of cardiovascular risk," The Journal of Nutrition, vol. 137, no. 10, pp. 2270-2278, 2007.

[6] K. D. R. Setchell, N. M. Brown, and E. Lydeking-Olsen, "The clinical importance of the metabolite equol-a clue to the effectiveness of soy and its isoflavones," The Journal of Nutrition, vol. 132, no. 12, pp. 3577-3584, 2002.

[7] C. Atkinson, C. L. Frankenfeld, and J. W. Lampe, "Gut bacterial metabolism of the soy isoflavone daidzein: exploring the relevance to human health," Experimental Biology and Medicine, vol. 230, no. 3, pp. 155-170, 2005.

[8] H. Sakakibara, D. Viala, A. Ollier, A. Combeau, and J.-M. Besle, "Isoflavones in several clover species and in milk from goats fed clovers," BioFactors, vol. 22, no. 1-4, pp. 237-239, 2004.

[9] A. Hoikkala, E. Mustonen, I. Saastamoinen, et al., "High levels of equol in organic skimmed Finnish cow milk," Molecular Nutrition and Food Research, vol. 51, no. 7, pp. 782-786, 2007.

[10] S. J. Gharpure, A. M. Sathiyanarayanan, and P. Jonnalagadda, " $o$-Quinone methide based approach to isoflavans: application to the total syntheses of equol, $3^{\prime}$-hydroxyequol and vestitol," Tetrahedron Letters, vol. 49, no. 18, pp. 2974-2978, 2008.

[11] Y. Takashima and Y. Kobayashi, "New synthetic route to (S)-(-)-equol through allylic substitution," Tetrahedron Letters, vol. 49, no. 35, pp. 5156-5158, 2008.

[12] C. Atkinson, S. Berman, O. Humbert, and J. W. Lempe, "In vitro incubation of human feces with daidzein and antibiotics suggests interindividual differences in the bacteria responsible for equol production," The Journal of Nutrition, vol. 134, no. 3, pp. 596-599, 2004.

[13] E. Bowey, H. Adlercreutz, and I. Rowland, "Metabolism of isoflavones and lignans by the gut microflora: a study in germfree and human flora associated rats," Food and Chemical Toxicology, vol. 41, no. 5, pp. 631-636, 2003.

[14] A. M. O'Hara and F. Shanahan, "The gut flora as a forgotten organ," EMBO Reports, vol. 7, no. 7, pp. 688-693, 2006.

[15] E. Furrie, "A molecular revolution in the study of intestinal microflora," Gut, vol. 55, no. 2, pp. 141-143, 2006.

[16] D. Tsangalis, G. Wilcox, N. P. Shah, A. E. J. McGill, and L. Stojanovska, "Urinary excretion of equol by postmenopausal women consuming soymilk fermented by probiotic bifidobacteria," European Journal of Clinical Nutrition, vol. 61, no. 3, pp. 438-441, 2007.

[17] A. Cassidy, J. E. Brown, A. Hawdon, et al., "Factors affecting the bioavailability of soy isoflavones in humans after ingestion of physiologically relevant levels from different soy foods," The Journal of Nutrition, vol. 136, no. 1, pp. 45-51, 2006.

[18] S. Bolca, S. Possemiers, A. Herregat, et al., "Microbial and dietary factors are associated with the equol producer phenotype in healthy postmenopausal women," The Journal of Nutrition, vol. 137, no. 10, pp. 2242-2246, 2007.

[19] L.-J. W. Lu and K. E. Anderson, "Sex and long-term soy diets affect the metabolism and excretion of soy isoflavones in humans," The American Journal of Clinical Nutrition, vol. 68, no. 6, pp. 1500S-1504S, 1998.

[20] I. R. Rowland, H. Wiseman, T. A. B. Sanders, H. Adlercreutz, and E. A. Bowey, "Interindividual variation in metabolism of soy isoflavones and lignans: influence of habitual diet on equol production by the gut microflora," Nutrition and Cancer, vol. 36 , no. 1, pp. 27-32, 2000.
[21] D. Vendrell, J. L. Balcázar, I. Ruiz-Zarzuela, I. de Blas, O. Gironés, and J. L. Múzquiz, "Lactococcus garvieae in fish: a review," Comparative Immunology, Microbiology and Infectious Diseases, vol. 29, no. 4, pp. 177-198, 2006.

[22] G. El-Baradei, A. Delacroix-Buchet, and J.-C. Ogier, "Biodiversity of bacterial ecosystems in traditional Egyptian Domiati cheese," Applied and Environmental Microbiology, vol. 73, no. 4, pp. 1248-1255, 2007.

[23] A. B. Flórez and B. Mayo, "Microbial diversity and succession during the manufacture and ripening of traditional, Spanish, blue-veined Cabrales cheese, as determined by PCR-DGGE," International Journal of Food Microbiology, vol. 110, no. 2, pp. 165-171, 2006.

[24] M. G. Fortina, G. Ricci, C. Picozzi, et al., "Phenotypic typing, technological properties and safety aspects of Lactococcus garvieae strains from dairy environments," Journal of Applied Microbiology, vol. 103, no. 2, pp. 445-453, 2007.

[25] C.-Y. C. Wang, H.-S. Shie, S.-C. Chen, et al., "Lactococcus garvieae infections in humans: possible association with aquaculture outbreaks," International Journal of Clinical Practice, vol. 61, no. 1, pp. 68-73, 2007.

[26] S. Yee, G. A. Burdock, Y. Kurata, et al., "Acute and subchronic toxicity and genotoxicity of SE5-OH, an equol-rich product produced by Lactococcus garvieae," Food and Chemical Toxicology, vol. 46, no. 8, pp. 2713-2720, 2008.

[27] FDA, “Guidelines for reproduction studies," In Redbook 2000: Toxicological Principles for the Safety Assessment of Food Ingredients, IV.C.9.a. Office of Food Additive Safety. Center for Food Safety and Applied Nutrition. U.S. Food and Drug Administration, Washington, DC, USA, 2000.

[28] FDA, "Guidelines for developmental toxicity studies," Office of Food Additive Safety. Center for Food Safety and Applied Nutrition. U.S. Food and Drug Administration, 2000, http://www.cfsan.fda.gov/ redbook/redivc9b.html.

[29] K. F. Kiple and K. C. Ornelas, "Soybean," in The Cambridge World History of Food, vol. 1, pp. 422-427, Cambridge University Press, New York, NY, USA, 2000.

[30] USDA, "USDA- Iowa State University Database on the Isoflavone Content of Foods, Release 1.4," Agricultural Research Service, Beltsville Human Nutrition Research Center, Nutrient Data Laboratory, Beltsville, Md, USA, 2007.

[31] L. Speroff, "Alternative therapies for postmenopausal women," International Journal of Fertility and Women's Medicine, vol. 50, no. 3, pp. 101-114, 2005.

[32] I. C. Munro, M. Harwood, J. J. Hlywka, et al., "Soy isoflavones: a safety review," Nutrition Reviews, vol. 61, no. 1, pp. 1-33, 2003.

[33] P. Phrakonkham, J. Chevalier, C. Desmetz, et al., "Isoflavonoid-based bone-sparing treatments exert a low activity on reproductive organs and on hepatic metabolism of estradiol in ovariectomized rats," Toxicology and Applied Pharmacology, vol. 224, no. 2, pp. 105-115, 2007.

[34] C. A. Lamartiniere, J. Wang, M. Smith-Johnson, and I.-E. Eltoum, "Daidzein: bioavailability, potential for reproductive toxicity, and breast cancer chemoprevention in female rats," Toxicological Sciences, vol. 65, no. 2, pp. 228-238, 2002.

[35] R. M. Sharpe, B. Martin, K. Morris, et al., "Infant feeding with soy formula milk: effects on the testis and on blood testosterone levels in marmoset monkeys during the period of neonatal testicular activity," Human Reproduction, vol. 17, no. 7, pp. 1692-1703, 2002. 
[36] K. L. Medlock, T. M. Forrester, and D. M. Sheehan, "Progesterone and estradiol interaction in the regulation of rat uterine weight and estrogen receptor concentration," Proceedings of the Society for Experimental Biology and Medicine, vol. 205, no. 2, pp. 146-153, 1994.

[37] K. L. Medlock, W. S. Branham, and D. M. Sheehan, "The effects of phytoestrogens on neonatal rat uterine growth and development," Proceedings of the Society for Experimental Biology and Medicine, vol. 208, no. 3, pp. 307-313, 1995.

[38] M. A. Thompson, B. L. Lasley, B. A. Rideout, and L. H. Kasman, "Characterization of the estrogenic properties of a nonsteroidal estrogen, equol, extracted from urine of pregnant macaques," Biology of Reproduction, vol. 31, no. 4, pp. 705-713, 1984.

[39] C. E. Wood, S. E. Appt, T. B. Clarkson, et al., "Effects of high-dose soy isoflavones and equol on reproductive tissues in female cynomolgus monkeys," Biology of Reproduction, vol. 75, no. 3, pp. 477-486, 2006.

[40] C. E. Wood, J. M. Hester, S. E. Appt, K. R. Geisinger, and J. M. Cline, "Estrogen effects on epithelial proliferation and benign proliferative lesions in the postmenopausal primate mammary gland," Laboratory Investigation, vol. 88, no. 9, pp. 938-948, 2008.

[41] D. Rachoń, T. Vortherms, D. Seidlová-Wuttke, and W. Wuttke, "Effects of dietary equol on the pituitary of the ovariectomized rats," Hormone and Metabolic Research, vol. 39, no. 4, pp. 256261, 2007.

[42] D. Rachoń, T. Vortherms, D. Seidlová-Wuttke, A. Menche, and W. Wuttke, "Uterotropic effects of dietary equol administration in ovariectomized Sprague-Dawley rats," Climacteric, vol. 10, no. 5, pp. 416-426, 2007.

[43] D. Rachoń, A. Menche, T. Vortherms, D. Seidlová-Wuttke, and W. Wuttke, "Effects of dietary equol administration on the mammary gland in ovariectomized Sprague-Dawley rats," Menopause, vol. 15, no. 2, pp. 340-345, 2008.

[44] D. Rachoń, T. Vortherms, D. Seidlová-Wuttke, and W. Wuttke, "Effects of dietary equol on body weight gain, intra-abdominal fat accumulation, plasma lipids, and glucose tolerance in ovariectomized Sprague-Dawley rats," Menopause, vol. 14, no. 5, pp. 925-932, 2007.

[45] K. L. Medlock, W. S. Branham, and D. M. Sheehan, "Effects of coumestrol and equol on the developing reproductive tract of the rat," Proceedings of the Society for Experimental Biology and Medicine, vol. 208, no. 1, pp. 67-71, 1995.

[46] D. Rachoń, D. Seidlová-Wuttke, T. Vortherms, and W. Wuttke, "Effects of dietary equol administration on ovariectomy induced bone loss in Sprague-Dawley rats," Maturitas, vol. 58, no. 3, pp. 308-315, 2007.

[47] A. S. Belloni, P. Rebuffat, L. K. Malendowlcz, G. Mazzocchi, S. Rocco, and G. G. Nussdorfer, "Age-related changes in the morphology and function of the zona glomerulosa of the rat adrenal cortex," Tissue and Cell, vol. 24, no. 6, pp. 835-842, 1992.

[48] T. D. Lund, D. J. Munson, M. E. Haldy, K. D. R. Setchell, E. D. Lephart, and R. J. Handa, "Equol is a novel anti-androgen that inhibits prostate growth and hormone feedback," Biology of Reproduction, vol. 70, no. 4, pp. 1188-1195, 2004.

[49] B. Kamińska, M. Opalka, and L. Dusza, "Phytoestrogens alter cortisol and androstenedione secretion by porcine adrenocortical cells," Acta Veterinaria Hungarica, vol. 55, no. 3, pp. 359367, 2007.

[50] J. M. Hamilton-Reeves, S. A. Rebello, W. Thomas, J. W. Slaton, and M. S. Kurzer, "Isoflavone-rich soy protein isolate suppresses androgen receptor expression without altering estrogen receptor- $\beta$ expression or serum hormonal profiles in men at high risk of prostate cancer," The Journal of Nutrition, vol. 137, no. 7, pp. 1769-1775, 2007.

[51] L. J. Lu, K. E. Anderson, J. J. Grady, and M. Nagamani, “Effects of soya consumption for one month on steroid hormones in premenopausal women: implications for breast cancer risk reduction," Cancer Epidemiology, Biomarkers \& Prevention, vol. 5, no. 1, pp. 63-70, 1996.

[52] S. Mesiano, S. L. Katz, J. Y. Lee, and R. B. Jaffe, "Phytoestrogens alter adrenocortical function: genistein and daidzein suppress glucocorticoid and stimulate androgen production by cultured adrenal cortical cells," The Journal of Clinical Endocrinology \& Metabolism, vol. 84, no. 7, pp. 2443-2448, 1999.

[53] C. E. Wood, J. M. Cline, M. S. Anthony, T. C. Register, and J. R. Kaplan, "Adrenocortical effects of oral estrogens and soy isoflavones in female monkeys," The Journal of Clinical Endocrinology \& Metabolism, vol. 89, no. 5, pp. 2319-2325, 2004.

[54] I. Matsuura, T. Saitoh, M. Ashina, et al., "Evaluation of a twogeneration reproduction toxicity study adding endopoints to detect endocrine disrupting activity using vinclozolin," Journal of Toxicological Sciences, vol. 30, pp. 163-188, 2005.

[55] R. K. Parshad, "Effect of restriction in daily feeding periods on reproduction in the female rat," Acta Physiologica Hungarica, vol. 76, no. 3, pp. 205-209, 1990.

[56] R. E. Chapin, D. K. Gulati, L. H. Barnes, and J. L. Teague, “The effects of feed restriction on reproductive function in SpragueDawley rats," Fundamental and Applied Toxicology, vol. 20, no. 1, pp. 23-29, 1993.

[57] T. Kishida, T. Mizushige, Y. Ohtsu, et al., "Dietary soy isoflavone-aglycone lowers food intake in female rats with and without ovariectomy," Obesity, vol. 16, no. 2, pp. 290-297, 2008 . 

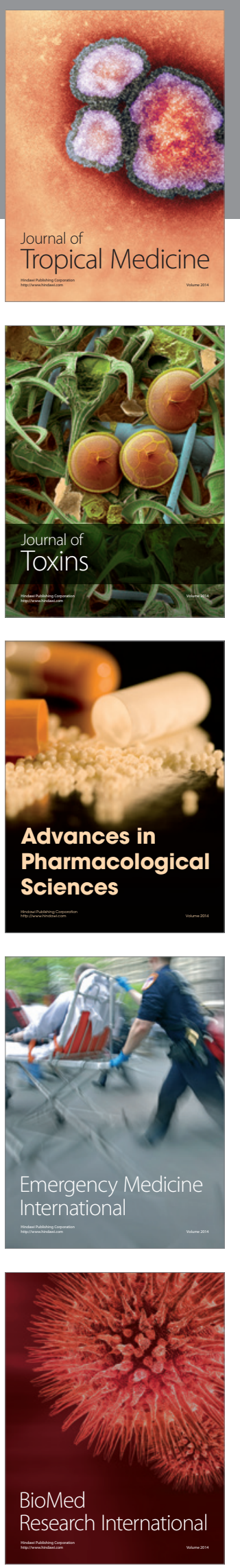
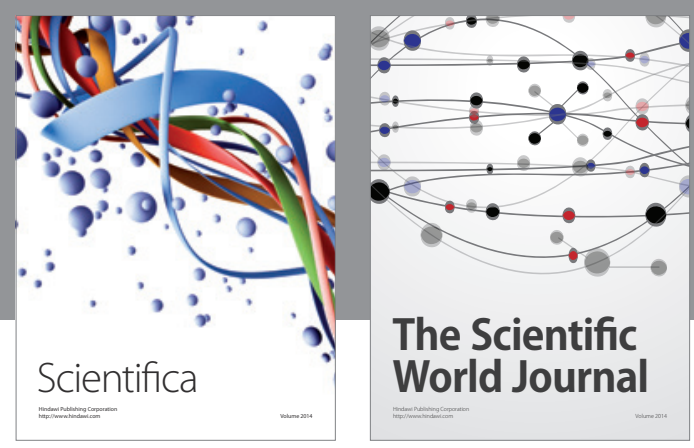

The Scientific World Journal
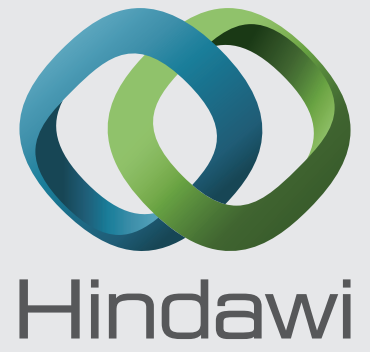

Submit your manuscripts at

http://www.hindawi.com
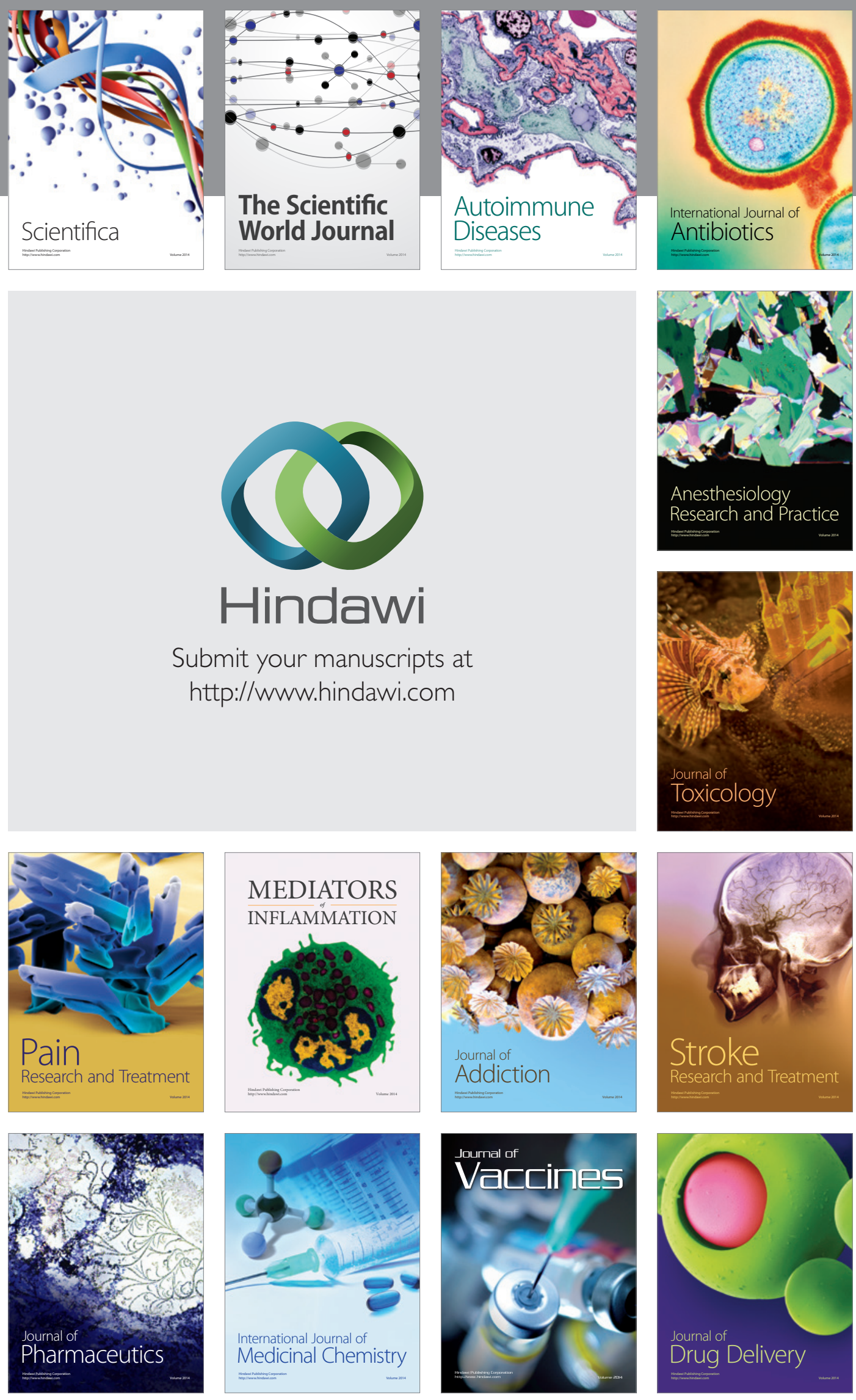